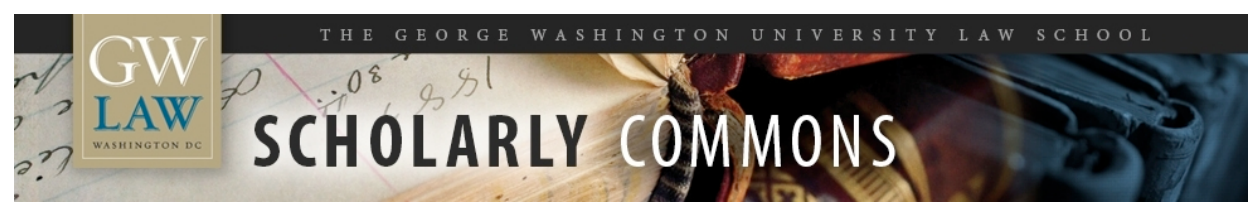

\title{
Johnson's Differentiation Theory: Is It Really Empirically Supported?
}

\author{
Joan S. Meier \\ George Washington University Law School, jmeier@law.gwu.edu
}

Follow this and additional works at: https://scholarship.law.gwu.edu/faculty_publications

Part of the Law Commons

\section{Recommended Citation}

Meier, Joan S., Johnson's Differentiation Theory: Is it Really Empirically Supported? (2015). Journal of Child Custody, Vol. 12, No. 1, pp. 4-24, 2015 ; GWU Law School Public Law Research Paper No. 2015-41; GWU Legal Studies Research Paper No. 2015-41. Available at SSRN: http://ssrn.com/abstract=2674853

This Article is brought to you for free and open access by the Faculty Scholarship at Scholarly Commons. It has been accepted for inclusion in GW Law Faculty Publications \& Other Works by an authorized administrator of Scholarly Commons. For more information, please contact spagel@law.gwu.edu. 


\section{JOHNSON'S DIFFERENTIATION THEORY - IS IT REALLY EMPIRICALLY SUPPORTED? ${ }^{1}$}

The feminist paradigm of domestic violence - which views it as a form of male domination of women - has been widely accepted among career domestic violence professionals (Mahoney, 1991; Dobash \& Dobash, 1979; Pence, E.). However, it has never been fully accepted by others who do not specialize in the field, including family court personnel, some researchers, and other critics. The countervailing paradigm - sometimes dubbed the "family violence" paradigm - treats domestic violence as a mutual and circumstantial problem, often suggesting that women are as violent as - or more violent than - men. (Straus, MenWeb Online Journal; Dragiewicz, 2008). Despite warring exchanges in both journals and courtrooms (Dutton, 2006; Straus, 2009; Rosen, Dragiewicz \& Gibbs, 2009)), neither side has ever succeeded in changing the other's opinion.

Michael Johnson's theory offers a solution to the pitched battle - by arguing that both camps are right (Johnson, 1995). A thoughtful sociologist with feminist credibility and identification, (Johnson, www.personal.psu.edu/mpg/MPG/Welcome.html), including a history of working with domestic violence shelters/programs, Johnson's differentiation theory has rapidly and remarkably gained traction among both feminist and non-feminist scholars and practitioners (Stark, 2009; Jaffe et al, 2008; Frederick, 2008; Ver Steegh and Dalton, 2008; Salem, 2007)

Johnson argues that the (feminist) paradigm of domestic violence as male domination and the (non-feminist) paradigm of mutual or female-initiated violence are both distinct parts of

\footnotetext{
${ }^{1}$ Joan Meier, Professor of Clinical Law, George Washington University Law School. Reader correspondence may be directed to Professor Meier at jmeier@law.gwu.edu.
} 
reality. Like the blind men feeling the elephant, he argues, each opposing camp feels a different part and insists it defines the whole animal. According to Johnson, each group is studying different populations, which manifest different types of domestic violence. Drawing upon preexisting research studies, he argues that violence driven by males' need for power and control is seen predominantly among populations urgently seeking shelter or legal assistance (on whom domestic violence advocates and scholars focus), while the anti-feminists are capturing in anonymous telephone surveys a more widespread kind of family violence which does not stem from male domination but rather from relationship conflict, and which is perpetrated by women as much or more than by men. Johnson's oft-repeated conclusion is that domestic violence can no longer be spoken of as a unitary phenomenon: because it can take such different forms, it must always be characterized as one type or another (Johnson, 2008).

The idea that there might be different types of violence between intimates is not novel (Pence \& Das DasGupta, 2006; Holzworth-Munroe \& Meehan, 2005; Straus, 2009). However, Johnson's theory, which purports to be empirically based and emanates from a self-identified "feminist," has, unlike prior theories, met with remarkably rapid and widespread adoption, especially in courts. "Differentiation" has rapidly become the new mantra in family law practice and many proposed reforms (Jaffe et al, 2008; Salem, 2007; Ver Steegh and Dalton, 2008). Among its strongest adherents are custody evaluators, who find his category "situational couple violence" useful in explaining why minor violence may be of little concern.

At least three factors help explain the remarkably quick integration of Johnson's theory into court practices: (i) his claim to empirical proof of his typology; (Johnson, 2008, 19, invoking "the evidence"); (ii) his suggestion that the two warring camps can be reconciled in a 
manner which enticingly offers an end to the gender wars; and most troublingly; and (iii) the usefulness of his validation of a "situational couple violence," which he describes similarly to the non-feminist "family violence" paradigm (described above), to family courts. Johnson's validation of the non-feminist, mutual, and situational violence paradigm - accompanied by his assertion that this type constitutes the vast majority of domestic violence - is especially appealing to family courts which frequently hear domestic violence allegations, but usually do not see them as raising serious concern for custody/visitation (E.J. v. D.J., 2011; C.A. v. J.B. 2011; In re Morrison \& Zacharia, 2009; Stephanie F. v. George C., 2012). Notably, despite the typology's growing use to legitimize minimization of domestic violence in family courts - other than this author's work, ${ }^{\mathrm{i}}$ only a single brief feminist critique has been published (Zorza, 2011).

This article begins to fill that gap, with particular focus on Johnson's claim to empirical "proof." Careful review of the research on which he relies suggests that, contrary to Johnson's assertion, the data he relies on does not support his typology, especially his claim that coercively controlling abuse is rare. Moreover, aspects of the research, and the typology itself, contradict other elements of the typology. I conclude that, although the differentiation approach warrants continued research and development, it is not yet ready for "prime time" in the courts - and in family courts, it is affirmatively destructive.

\section{Overview of the Theory}

Johnson's theory emanates from a potentially brilliant resolution of the gender wars over the feminist paradigm of domestic violence. Johnson theorizes that the two embattled views are merely an artifact of the fact that different professional groups study different populations. i.e., a product of "selection bias." He states that domestic violence advocates and researchers are 
focused on victims seeking services, such as shelter or legal protection, and these victims are more afraid, more endangered, and more likely to be female victims of male violence aimed at power and domination. Hence, these researchers, lawyers, and advocates developed the power and control paradigm based on their experiences with such victims.

In contrast, he argues, "family violence" researchers such as Murray Straus, who do not work with clients, but rather, study survey populations through anonymous phone surveys, are tapping into a completely different population. These findings that men and women appear to be at least equally violent to each other, or that women are more violent reflect a different population, which is experiencing "common couple violence." Relatively few "male domination" cases are found in surveys, Johnson argues, because women in such relationships are too at risk to be able safely to participate in a survey. Conversely, men and women involved in mutually violent or non-oppressive violent relationships were likely to be less fearful and less at risk, and therefore less likely to seek services such as shelter or legal protection.

To capture these two different paradigms of domestic violence, Johnson coined two categories: "Common Couple Violence" (CCV; later termed "Situational Couple Violence" $(\mathrm{SCV}))$ and "Patriarchal Terrorism" (later termed "Intimate Terrorism" (IT)). The first type is "violence that is not connected to a general pattern of control involving specific arguments that escalate to violence" (Johnson and Leone, 2005). The second type is "the attempt to dominate one's partner and to exert general control over the relationship, domination that is manifested in the use of a wide range of power and control tactics, including violence" (Johnson and Leone, 2005). Johnson emphasized that Intimate Terrorism is what feminist writers and advocates have meant by "domestic violence." According to Johnson, it is committed "almost entirely" by men 
against women, and is linked to patriarchal attitudes (Johnson, 2008, p. 2). Johnson also asserts that SCV is far more common than IT (Johnson, 2008, 2).

How do the two types of domestic violence differ in impact? Johnson has described $\mathrm{CCV} / \mathrm{SCV}$ as less severe, less frequent, and less likely to escalate (Johnson, 2008, 23), though he has also acknowledged that it can be serious (Johnson, 2008, 62) and even homicidal (Johnson 2008, 33 n. 32). He believes intimate terrorism to be " the type most likely to be frequent and brutal" and to escalate (Johnson, 2008, 23, 25). According to Johnson, IT victims have more injuries, pain, health impact, post traumatic stress disorder, and loss of work than SCV victims (Johnson and Leone, 2005). In an important caveat, Johnson also states that severity and frequency do not exclusively define each type, although the types do differ "on average" (Johnson and Leone, 2005). Rather, he emphasizes that the defining distinction between types is the presence or absence of the motive to keep control over the partner - not the severity of the violence.

Johnson's four types thus break down as follows: Situational Couple Violence (roughly equal distribution across genders, sometimes but not always mutual violence); Intimate Terrorism (mostly men); Violent Resistance (mostly women); Mutual Violent Control (both parties) ${ }^{\text {ii }}$. His bottom line is that it is no longer scientifically or ethically acceptable to speak of domestic violence without specifying, loudly and clearly, the type of violence to which we refer (Johnson, 2005).

\section{Differentiation's Value}

Johnson's enterprise of distinguishing between violence used to enforce a regime of terror and control and violence which is expressive or conflict-driven but does not instill ongoing fear, 
is a valuable addition to the field. There should be no question that some violence between couples is not part of a larger control dynamic; some is simply a function of conflict run amok; and some may reflect mental illness or other disorders. From a feminist perspective, recognition that some violence between intimate partners exists which does not fit the gender-oppressive paradigm of "battering" helps to distinguish women's use of violence from the "true abuse" (usually male vs. female) typically understood to be meant by the term "domestic violence."

Moreover, the intimate terrorism paradigm's defining characteristic of power and control helpfully underlines the feminist argument that control-type abuse is a means of men's subordination of women (Pence and Dasgupta, 2006; Bancroft, Silverman, \& Ritchie, 2012; Mahoney, 1991). Insofar as the law, which focuses solely on discrete incidents of violence and not on how it is used or the control dynamic within which it may be embedded, has not reflected the power and control paradigm (Stark, 2006; Tuerkheimer, 2004), Johnson's emphasis on the power and control lends support to the feminist argument.

Johnson's depiction of the power and control at the heart of battering (which he calls “intimate terrorism") "joins a line of analysis" which has been amplified for decades by prior feminist researchers (Stark, 2006, p. 1021). However, none of his predecessors have drawn on a broad empirical basis synthesizing data across major studies, as Johnson purports to do, nor provided, as Johnson does, a resolution to the feminist domestic violence and "family violence" researchers' standoff regarding what domestic violence really is. Both Johnson's theory of selection bias and his typology are elegant and intuitively appealing, and they likely capture at least portions of the truth. 


\section{Differentiation's Damage}

Johnson's call for recognition that some domestic violence is better labeled "situational couple violence," while widely adopted with little critique, raises significant concerns among many working with battered women - particularly in custody litigation. Family courts have been increasingly recognized as very dangerous territory for adult and child abuse victims (Hannah and Goldstein, 2009; Jaffe, Crooks and Poisson, 2003; Neustein \& Lesher, 2005; Stark, 2009; Lemon, Jaffe \& Poisson, 2003; Meier, 2003). In these circumstances, a theory that can contribute to custody courts' minimization of the implications of abuse or domestic violence is necessarily of concern.

By asserting that SCV is far more common than IT and is generally less severe, Johnson's typology intrinsically validates the old view that most violence between partners is not gendered, is mutual, or simply a function of conflict rather than dominance or oppression. Most importantly, this view presumes that most domestic violence allegations are not terribly concerning. The following cases are only a few examples of cases found in published opinions indicating that the "situational" moniker is indeed being used to justify ignoring or minimizing of domestic violence in the custody context. Based on reports from advocates in the field, it is likely that this use of the label - to minimize domestic violence - is quite widespread.

\section{Case 1}

In this case, the court initially found that Mr. J had committed two legally cognizable assaults against his wife, including an instance of shaking and throwing her on a bed, and an instance of wrapping a dishcloth around the back of her neck during an argument and pulling her toward him. The court rejected Ms. J's testimony that he actually crossed the dishtowel in front 
of her neck and began to choke her. Nonetheless, the court minimized its own findings of domestic violence, based in large part on a custody evaluator's opinion that the violence Ms. J had experienced was merely "situational couple violence" (E.J. v D.J., Appellant's Brief, 2011, n. 26). Based on this label, the evaluators and judge concluded that there were no concerns for the well-being of the children, that the older girl's fear when with her father and her refusal to see or talk to him, were entirely unfounded, best explained as a product of her mother's "excessive" fear and hostility toward her ex-husband. ${ }^{\text {iii }}$ The situational couple violence label was a convenient way for both the evaluators and court to neutralize the court's own findings that the father had twice committed physical abuse, and, importantly, to shed the protective statutory mandate triggered by those findings (E.J.v D.J., 2011).

Thus, this court awarded joint custody and a number of other conditions, which were inappropriate in light of the history of violence (e.g., parenting mediation with a parenting coordinator). The mother continued to raise concerns about the children when parented by the father, and refused to treat the father as a harmless and decent parent. As a result, both children were ultimately removed entirely from their mother (who had never committed any abuse) and awarded to their father (an adjudicated perpetrator), and the older one was forbidden to see her at all, as a purported cure for her so-called alienation (Meier, 2009).

\section{Published Decisions}

Similarly, Maine's Supreme Court affirmed a trial court's award of unsupervised visitation to a father who the mother had accused of a history of domestic violence. The appellate court quotes the Guardian Ad Litem's opinion in the following section:

[T] he guardian concluded that the episodes of domestic violence were attributable to "situational couple violence' arising from conflicts in the marriage, as opposed to 'coercive controlling 
violence, "which is characterized by power and control and often results in serious injuries. . . This is not a typical domestic violence situation, in that the person with the power and control in the relationship was clearly [mother]... '’(Malenko v. Handrahan, 1272).

In C.A. v. J.B., the appellate court affirmed the trial court's finding that there was no [pattern] of violence in either home. Much has been made of the battery case flowing from the parties break up, but under the Court's understanding of current domestic violence analysis, this appears to be an incident of Situational Couple Violence or more likely Separation Instigated Violence rather than the Coercive Controlling Violence which would give the court great concern. Under this analysis, this factor only slightly favors the mother (C.A. v. J.B., 2011, 5-6). The appellate court went on to reject the mother's spirited arguments that her two past ex parte orders against the father, in addition to the father's criminal conviction for battery, as well as the lack of expert support for the trial court's labels rendered its use of the SCV label an abuse of discretion (Id.). In a California case, the appeals court affirmed the trial court's refusal to allow a mother to relocate with her child and description of the father's conceded pushing of her during an altercation as "merely" situational couple violence, despite a prior history that led to a restraining order (In re Morrison \& Zacharia, 2009). Furthermore, at least one appellate court has endorsed a trial judge's finding that the "situational" label for domestic violence was sufficient to rebut a statutory presumption against joint custody to a perpetrator of "domestic violence" (Stephanie F. v. George C, 2012).

In most of these cases, the mothers had sought or received protective legal measures, including protective orders, arrest, and/or criminal convictions. In Johnson's typology, that helpseeking is indicative of "intimate terrorism" and not situational couple violence - or at most, serious enough violence to stimulate fear and legal action. Nonetheless, each of these courts 
minimized the domestic violence history as merely "situational," and therefore not subject to existing statutory restrictions based on domestic violence. While it may be unfair to lay these arguably inappropriate applications of Johnson's typology at his doorstep, to many domestic violencelawyers, precisely this use of his types was predictable, particularly given his assertion that SCV - and not controlling abuse - is the "norm."

While in none of these cases did the "situational" label alone cause the troubling judicial outcome (including, in E.J. v. D.J., complete loss of custody from a non-offending and concededly fit mother), in each case it reinforced and facilitated the use of other theories and analyses, including parental alienation, which minimized the significance of a father's past violence to the mother, and arguably, even to the child ${ }^{\text {ii }}$ Had the SCV label not been available, the courts would have been less able to write off the domestic violence as irrelevant to custody. Instead, the "situational" label allowed them to essentially ignore the history of abuse, to treat it as "violence with a small v," (E.J. v D.J. Appellant's Brief, 44), and on that basis, to ignore the statutory constraint intended for "domestic violence." It should be noted that at least one of these cases (E.J. v. D.J.) occurred within a court known for its commitment to domestic violence through a dedicated Domestic Violence Unit, and which has advanced a number of onceprogressive reforms (Epstein, 1999)

These cases reflect the trend in family court toward rapid and broad adoption of Johnson's (and similar) categorizations (Kelly and Johnson, 2008; Jaffe, Johnston, Crooks \& Bala, 2008; Ver Steegh \& Dalton, 2008). The assimilation of the SCV paradigm in family courts is furthered especially by Johnson's repeated assertions that it is situational couple violence which is the norm, and intimate terrorism which is rare (Johnson, 2008, 11; Johnson \& Leone, 2005). This 
assertion, again playing into many peoples' intuitive minimizations of the breadth and seriousness of abusive violence, has reinforced widespread assumptions that those who litigate custody are not that different from most of us, and therefore allegations of abuse there need not be presumed serious (Zibell, 2005; Ver Steegh, 2005). In fact, a growing number of forensic evaluators have asserted that the majority of the cases they see involve only situational violence, and not "power and control" violence (iii (Stark, 2009, 307; Saunders et al, 2011, 6). This view is predictable, because the SCV concept converges easily with other widespread but scientifically dubious theories like parental alienation, which similarly treat abuse allegations as either insignificant or affirmative evidence of a pathological or vengeful mother's malevolent drive to exclude the father from the children's lives (Jaffe, Johnston, Crooks \& Bala, 2008; Meier, 2009).

In Johnson's defense, neither his publications nor the research upon which he relies explicitly claims that the differing types of domestic violence necessarily correlate to differing risks to children after separation. Thus, it could be argued that the theory was never intended to apply to custody and visitation decisions. However, while Johnson certainly does not appear to have given much thought to the implications of his theory for custody battles, he does problematically imply that custody litigants may be similar to the phone survey respondents, i.e., more like a random sample of the population, rather than that relatively small slice of the population which he believes comprises couples involved in IT (Johnson, 2008, 81-82). Moreover, the following comment indicates Johnson is entirely unfamiliar with the realities facing women who battle abusers for custody: "If a woman has been so psychologically abused that she believes her partner really can get the courts to give him custody of the children if she 
leaves him, how can she in good conscience abandon them to him?" (emphasis added) (Johnson, 2008, 54). Perhaps if he were acquainted with the disastrous outcomes facing thousands of abused women and children in family courts, (see pp. --- above), he would have thought differently or more carefully about his typology.

\section{Empirical Critique}

If Johnson's typology were verifiably correct and relevant to outcomes for children, this critique would aim solely at custody courts' misapplications of it, and not at the theory itself. But in fact, not only does the theory lack attention to the implications for custody litigation, its empirical underpinnings are actually quite debatable, and his most significant empirical conclusion in itself contributes to the problems in family courts. It is the theory itself, therefore, at which I aim this critique.

What makes Johnson's SCV concept so powerful in the hands of custody professionals who are skeptical about abuse is Johnson's prevalence claim: If it is true that SCV is the primary paradigm in the population, it is a small leap to the assumption that it is also likely the norm among custody litigants. This assumption - that custody litigants are not much different from the general population - and hence that their domestic violence likely mirrors the situational couple violence Johnson asserts is most common, validates family courts' assumptions that most of the abuse claims before them are over-dramatized illegitimate claims about conduct which should not determine a parent's right to custody. If, however, Johnson's numerical assertions are incorrect, and coercively controlling violence is actually more widespread than situational violence, then the conventional wisdom in family court - that most domestic violence is not serious - would be powerfully challenged. 
Johnson himself touts the theory's empirical foundations. In his definitive book, he states that his "argument" was first published in 1995 and "seemed reasonable enough," but only subsequently could he offer "the evidence" (Johnson, 2008, 19). The evidence to which he refers consists of multiple different data sets and studies by others, which he asserts demonstrate both that the different types are real and that they can be quantified.

But this "evidence" is far less determinative than he suggests. This is important not only because it reduces the scientific proof that his typology is accurate, but more importantly, because it dismantles his repeated assertion about the relative prevalence of SCV and IT - an assertion which is widely believed by courts, to the detriment of survivors of abuse.

\section{Problems with the Quantitative Analysis}

After theorizing the different types, Johnson opens his empirical discussion thus: "Here is the evidence:" (Johnson, 2008, 19). His "evidence," however, is flawed in at least two respects. First, the research he relies on was not undertaken to focus on control, and hence it tends to measure various behaviors which may or may not really reflect relationship control. Second, his own empirical findings in certain respects contradict his types. Third, and most important, his prevalence claim is based on a "cluster analysis" of the data which uses an arguably inappropriately high threshold to distinguish between "high control" (IT) and "low (or non) control" (SCV) cases. Independent research suggests that a lower threshold may be more apt, resulting in a reversal of Johnson's assertion about prevalence of SCV vs. IT (Frye, Manganello, Campbell, Walton-Moss \& Wilt, 2006).

\section{Use of Old Data Sets Not Intended to Measure Control}


Johnson's empirical analysis is not based on any original research. Rather, he reanalyzes existing data sets from prior studies, none of which, with one partial exception, were gathered with this typology in mind. His findings are thus limited by the data sets, which (with one exception) were not themselves measuring coercive control in any depth. While he acknowledges the limitations of these data, he nonetheless suggests that they "prove" his theory is true.

For instance, Johnson draws on the Effects of Violence on Work and Family Study to identify as proxies for control certain behaviors that were measured in that study (Johnson, 2008, 97). Those behaviors included swearing, accusing, and saying things to spite - behaviors which are not necessarily "control" behaviors - yet many of the more recognized and fundamental control behaviors, such as economic control, isolation, and control of daily life, were not measured. Based on these data, which do not capture key controlling behaviors, and using categories which appear questionable, Johnson and his colleagues conclude that far more couples fit the SCV type than the IT type (Leone et al, 2004, 485-486). ${ }^{\text {iv }}$

\section{Are the Categories Really Distinct, and Is SCV Really the Dominant Type?}

Johnson's strongest evidence for his typology comes from a particular data set: Irene Frieze's 1970's Pittsburgh study of three groups of women: (i) women seeking legal protection or shelter, (ii) women responding to a flyer for the study, and (iii) a comparison neighborhood sample. This study is valuable for his theory both because it did explicitly measure controlling behaviors and because it analyzed both a litigation sample and a neighborhood sample, thus drawing on the two differing populations he seeks to differentiate. Yet, it is this study that produces, for Johnson, the most surprising result: Contrary to his theory, the data indicate that 
almost half of the couples in the shelter and legal sample qualify (in his terms) as cases of $S C V$ (Johnson, 2008, 21). After expressing his surprise at the inconsistency of this finding with his hypothesis that most agency samples reflect IT cases, he concluded that it can be explained by recognizing that even in SCV cases, some violence is frightening enough for women to seek shelter (Johnson 2008, 21)

This adjusted position may be correct, but if it is, it indicates a fault line in his theory. Indeed, he recognizes the troubling implication for his categories when he writes "where did I go wrong?” (Johnson 2008, 21). The significant presence of so-called SCV cases in the agency sample suggests one of three things: Either (i) SCV is potentially at least as frightening, dangerous, and possibly gendered, as IT (leading women to flee their home and seek shelter), contrary to his over-arching theory that SCV is non-gendered, not usually serious, and rare in help-seeking samples; (ii) he has mis-characterized as SCV cases those that should have been categorized as IT; or (iii) the control factor is not in fact sufficient to differentiate serious and one-way abuse from "common couple" violence which is presumably less concerning from both a consequential and gender equality perspective. Any one of these possibilities, which in combination are probable, is sufficient to explode the core distinction between IT and SCV: suggesting that SCV may be equally or more dangerous than IT and equally gendered with male aggressors and frightened female victims (Anderson, 2009, 1453-1454). At minimum, this "surprising" result suggests that many of the cases Johnson counts as SCV may in fact be IT, thereby potentially reversing his prevalence claim, with significant implications for custody in particular. 
A similar problem for Johnson's typology emerges in his and a colleague's analysis of the National Violence Against Women Survey (NVAWS) data. The NVAWS data is also quite important for Johnson because, like the Pittsburgh study, it is solely based on a telephone survey of the general population (thus, presumably capturing SCV), and it also included questions related to control (Johnson \& Leone, 2005; Johnson, 2008, 93). But, as with the Pittsburgh data, Johnson's honest and transparent analysis contradicts his expectation: he finds a "surprisingly high representation (35\%) of intimate terrorism among the violent men in this sample" (Johnson, 2008, 330). This contrasts with his hypothesis - which he claims to have been proven by this very data - that general survey respondents are only very rarely involved in IT (Johnson, 2008, 330). He explains this confounding result by suggesting that the NVAWS is more a "crime" survey than a general "families and conflict" survey, which, he suggests, nets more respondents describing violence experienced "in a general context of control" than those who might have experienced "more isolated" violence (Johnson, 2008, 330).

This explanation is unsatisfying, especially given that it directly contradicts his theory's foundational premise - that population surveys will not flush out IT relationships. Furthermore, when placed next to the "confounding" results of the Pittsburgh data analysis, it again suggests that Johnson's idea of clean and distinct types of intimate violence which correlate fairly neatly with two different data sources is, at the least, not proven by these quantitative analyses and may even be disproven. Going further, if one takes these results at face value, without speculations about who answers which surveys in what ways, this result suggests that intimate terrorism may be occurring among at least one third of the general population - in clear contradiction to Johnson's repeated assertion that IT is quite rare. 


\section{More Mis-Categorizing: High Cut Points in Cluster Analysis May Reverse Actual Prevalence}

As noted above, arguably one of the most significant aspects of Johnson's theory is his assertion, drawn from his analysis of general survey data, that the vast majority of domestic violence in the population is SCV, and that IT is relatively rare (Johnson, 2008, 2). However, when one examines the analysis on which he bases this claim, it appears arbitrary at best and incorrect at worst.

Johnson's "cluster analysis" of the data in each study plots the couples along a scale of increasing numbers of control behaviors and then identifies "clusters" of data points. He then draws a line between the primary clusters, treating the cluster which is higher on the scale as the "high control" group and the lower cluster as the "low control" group (Johnson, 2008, 90). He then defines the group with the higher number of control behaviors as IT, while denominating couples with the lower number of control behaviors as SCV.

The first problem with this approach is that Johnson does not explain why couples anywhere on these scales don't all qualify as "coercive control" couples, i.e., why even the use of just one or two of the control behaviors is not sufficient to create coercive control. Nowhere does Johnson explain why he assumes that a small number of controlling behaviors is not coercive control and is merely "situational" violence. However, he offers a hint when he says "[e]ach of the scales discussed above produces a continuum of coercive control that must be dichotomized if one is to create the proposed typology" (Johnson, 2008, 90). It appears that, because he is determined to find two distinct types, he must characterize the groups with greater and lesser numbers of controlling behaviors as different types. However, this dichotomizing risks mistakenly characterizing as SCV even couples where one party uses one control behavior 
(possibly supplemented by other control behaviors that these arbitrary data sets did not happen to measure) along with sufficient violence to generate control of the other partner. This problem is consistent with the point noted above, that his own quantitative analysis of the Work and Family study suggests that as many as $1 / 3$ of the couples Johnson is characterizing as SCV have indications of IT (Johnson, 2008, 97). ${ }^{\mathrm{V}}$ The second problem is that in most of the studies, Johnson defines high control as three or more behaviors. Thus, couples with two or fewer types of control behaviors are categorized as non-controlling relationships, i.e., SCV. (Johnson, 2008, 93, 94, 101; Johnson \& Leone, 329). ${ }^{\text {vi }}$

In at least some of these analyses, Johnson appears to have chosen an inappropriately high bar to define "controlling" relationships. Surely it is reasonable to suggest that couples with three or four controlling behaviors qualify as coercive control couples. The same might also be said for two, or even one, controlling behavior - depending on the seriousness of the particular control behavior, its context, or its impact. Indeed, if one compares them to violent relationships which lack any of these controlling behaviors, relationships with even one control behavior might properly be categorized as "control-based" violent relationships. It seems likely that if the "low control" populations are treated as still within the IT category, the prevalence of coercive control relationships and situational couple violence relationships would become reversed: the vast majority would now involve control-based violence.

This hypothesis is confirmed by a study which was specifically designed to assess Johnson's categories, consisting of original research by a leading empirical researcher. Jackie Campbell is the nation's leading researcher of femicide and has used empirical research to develop and validate her danger assessment tools (http://dangerassessment.org/AboutCreator.aspx). 
Campbell and her co-authors' original research applying Johnson's categories found relationships with one controlling behavior to be $69 \%$ of violent couples (Frye, Manganello, Campbell, Walton-Moss \& Wilt, 2006). Concerning Johnson's own higher cut-point of three control behaviors, the authors stated:

The choice of 3 as a cut-point for controlling behaviors for assaulted women seems high. ... [E] ach of the other four controlling behavior items included in our index indicate serious attempts to control either the time, contacts or access to financial resources of the respondents, and on their face, cannot be conceived of as innocuous relationship behaviors... it is the frequency with which tactics are used and how much control is achieved, rather than the number of different tactics that makes a difference....

The authors conclude that SCV may be "the least common" form of domestic violence "at the population level," in direct contradiction to Johnson's repeated prevalence assertions (Frye, Campbell, Manganello et al, 2006, 1305).

\section{Theoretical Inconsistencies}

TWhile the focus of this article is on the problems with Johnson's empirical claims. a few theoretical problems must also be pointed out.

(i) Different types of abuse or different stages in time?First, it is unknown to what extent the types actually describe the same relationships at different stages, rather than in different couples. As a practical (or experiential) matter, it is eminently possible that some degree of violence arises in relationships before they become generally controlling, but that over time, the violence instills fear, and the perpetrator becomes increasingly controlling. This hypothesis was articulated by the Campbell study authors, who also identified empirical support for it: In their

study, the IT couples were older than the SCV couples, which would be expected if SCV couples were simply earlier in an abusive relationship trajectory (Frye, Manganello, Campbell et al, 
2006). Of course, if the same couples are appearing in both categories at different stages of their relationship, the distinction between types becomes far less salient, because over time they become essentially the same, meaning that future dangerousness and other long-term implications can no longer be distinguished. Thus it is not at all clear that the implied characteristics attached to the SCV label (less dangerous, more mutual, less relevant to child custody) apply.

\section{(ii) Control is unavoidable in one-sided violence}

Second, Johnson's SCV category was originally named "common couple violence" and regardless of label, is intended to capture the kind of physical engagement that one envisions in,

for instance, sibling fights or barroom brawls. In other words, it is physical fighting in response to conflict, but it is not embedded in a larger intimidating dynamic of power, control, and subordination. Johnson repeatedly emphasizes that SCV can be either mutual or one-sided, so long as it is conflict-driven and not part of a larger controlling or oppressive dynamic. He also portrays SCV as, for the most part, more minor, more mutual, and less fear-inducing than “intimate terrorism" or control-based violence (Johnson, 2008, 61-62, 69-70). But one-sided "situational" violence is necessarily intimidating, especially when it is male against female. If one party is the perpetrator and the other the victim, it is hard to imagine there being no power dynamic, no fear, and no control. This is particularly true in light of the reality that, on average, women are both less equipped and less able to fight, especially with men, and they suffer far greater injuries and other negative consequences from men's assaults, than the reverse (Swan \& Snow, 2002, 290; Anderson, 2009, 1449). "With some exceptions, men generally do not perceive women as intimidating or frightening" (Swan \& Snow, p. 291-292; Johnson, 2008, 21, 
62, 70). More recent research further confirms that the impact of "situational" violence is highly gendered, i.e., even in purportedly "situational" violence, women suffer greater physical and mental health consequences than men, including with respect to their levels of fear (Sillito, 2012).

However if one partner is afraid of the other, some degree of power imbalance and control by the violent partner is inevitable. It is hard to imagine a relationship in which the man is violent to the woman (or the reverse), yet takes no advantage of the power or control this affords him in the relationship. Additionally, if non-mutual SCV involves some degree of control, this cuts across Johnson's core distinction between the two types. This logical analysis converges with the quantitative discussion earlier, which indicated that there may be hidden "IT" among the populations Johnson characterizes as "SCV."

This hypothesis is actually supported by the Pittsburgh data mentioned above, which, as previously mentioned, Johnson sees as foundational to his theory. Johnson expressed "surprise" when this data showed that as many as $31-32 \%$ of the agency sample - which his theory predicted would be IT - actually involved (as he defined it) SCV. His response is instructive: [T] here are considerably more cases of situational couple violence [in the agency data] than I had thought there would be. Where did I go wrong? I had mistakenly assumed that only intimate terrorism would frighten women enough to send them to the courts for a Protection from Abuse order, or to a shelter for support or temporary housing. I hadn't paid close enough attention to my own statements that even situational couple violence can be quite frequent and/or severe. And I hadn't taken seriously enough the evidence from general surveys (thus dealing with situational couple violence) that men's situational couple violence is much more likely than women's to produce injuries. Shelters and courts are places that women turn to when they fear for their safety. . . situational couple violence involving a man assaulting a woman can also be severe enough or frequent enough to be quite frightening (Johnson, 2008, 21).

This is undoubtedly true, yet this "recovery" does not go far enough: As already suggested, if women are afraid and seek legal or physical protection from their male partner, it is likely that 
the partner has derived from their intimidation some illegitimate "power" or "control" over them, which is more than the normal give and take in a healthy relationship. If so, the key defining distinction between SCV and IT breaks down.

There is still another deeper fault line in Johnson' typology:: Suppose these one-sided and gendered "SCV" cases do not in fact involve a coercive controlling agenda. Must we not then acknowledge that control is not the only indicator of serious and gender-oppressive abuse? That is, in any of the cases described above, the perpetrator's abuse may well have been correctly characterized as "situational," assuming he did not in fact seek to control the mother's access to resources, employment, or freedoms, apart from the child. However, that did not mean that the perpetrator posed no danger to the mother or the child going forward. Indeed, insofar as most of the cases indicated a past history of help-seeking and legal protective interventions, there is good reason to believe these women were realistic in asserting future danger.

\section{(iii) Intimate Terrorism Label Misleadingly Implies Severe Overt Violence}

(3) Not only is Johnson's definition of situational couple violence potentially inaccurate, his definition of intimate terrorism is also likely unduly narrow in a manner which similarly misleads courts and evaluators to minimize real danger. Johnson defines intimate terrorism as follows:

The intimate terrorist uses physical violence in combination with a variety of other control tactics to exercise general, coercive control over his partner. . on average, male intimate terrorists are frighteningly violent.(Johnson, 2008, 26, 30).

This definition implies that intimate terrorism is the kind of violence that anyone would recognize as seriously dangerous: The very label "terrorism" inevitably implies lethal and disastrous levels of violence, although Johnson hedges at times (Johnson, 2008, 30). ${ }^{\text {vii }}$ In 
contrast, the label "situational [or "common"] couple violence" intrinsically minimizes the severity of any violence and makes it sound mutual.

Contrary to the IT label's implication, coercively controlling relationships are often not highly violent; in fact, in upper socioeconomic status relationships, the violence is usually suppressed but control is often extreme (Stark, 2006, 1021; Waits, 1998; Weitzman, 2000). ${ }^{\text {viii }}$ For instance, in one of my earliest cases, the wife, an attorney, was under the dominance of her husband, also an attorney, down to the most minute details of her day (JML v. CAL, Appellant's Brief, 9). ${ }^{\text {ix }}$ The only physical violence that was evident, however, involved "cornering" her or pinning her on the bed and yelling in her face. Sexual abuse was also present, generally involving coercion and force but not overt physical violence. My own experience with such cases, as well as the cases and research described above, indicates that extreme violence is the exception, not the norm, in these "upscale" marriages, with the possible exception of sexual abuse (JML v CAL, Appellant's Brief at 8; Weitzman, 2000, 18; Waits, 1999, n. 164).

It must be acknowledged that the lower level of overt physical violence that is prevalent in upscale abusive marriages is not the kind of violence that impresses family court judges. This begs the question: Should extreme coercive control, lacking overt violence, be given significant weight in the custody context? Perhaps - especially insofar as coercive control may be indicative of serious future risk. But as a practical matter, such a relationship is unlikely to be seen as amenable to the label "intimate terrorism." If there is little actual physical violence, the label appears incongruous. Even now, evaluators and judges deem coercive control insignificant, especially if the overt violence is minimal. ${ }^{\mathrm{x}}$ In short, "the failure to identify abuse is perpetuated by its equation only with severe, unilateral violence" (Stark, 2009, 312). 


\section{The Ever-Changing Types}

It is possible that Johnson himself recognizes the ambiguities of his types; indeed, he has repeatedly revised his categories and their definitions, particularly with respect to dangerousness and severity of violence. For instance, in the first article, he described "common couple violence" as involving relatively infrequent and non-escalating minor violence by both genders in roughly equal amounts and "patriarchal terrorism" as involving frequent and escalating severe one-way violence by men against women (Johnson, 1995, 285 et seq). Later, he took pains to state that SCV is not necessarily mutual, that a substantial portion of it does escalate, and that it can be quite severe (Johnson \& Leone, 2005, 333; Johnson, 2008, 62, 69). He also acknowledged that intimate terrorism can in fact involve only minor and/or infrequent physical violence (Johnson, 2008, 29).

Unfortunately, while Johnson's writings have become increasingly peppered with caveats, the very act of defining types intrinsically requires generalizations. The more nuanced and variable the categories become, the more the types intersect and overlap, undermining the very concept of distinct types and inviting mis-applications. Thus, while there are undoubtedly differences in types of violence within different couples and these may have differential impacts on children and adults, Johnson's typology is both empirically and theoretically contradicted and subject to doubt. Given the damage this typology is already contributing to in the family courts, going forward, it warrants considerable skepticism until such time as adequate empirical foundations and theoretical definitions can be identified.

\section{REFERENCES}

Anderson, K.L. (2009). Gendering Coercive Control, Violence Against Women 15: 1444 
Bancroft, L., Silverman, J.G. \& Ritchie, D. (2012). THE BATTERER AS PARENT 2d Ed (Sage Publications)

C.A. v. J.B. (2011). Ind. App. Unpub. LEXIS 957 (Ind. App.)

Dobash, E. \& Dobash, E. (1979). VIOLENCE AGAINST WIVES (The Free Press)

Dragiewicz, M. (2008). Patriarchy Reasserted: Fathers'Rights and Anti-VAWA Activism, 3:2 Feminist Criminology 121-144

Dutton, D. G. (2007). RETHINKING DOMESTIC VIOLENCE (University of British Columbia Press)

E.J. v. D.J. (2011). Brief of Appellant, available at

http://www.dvleap.org/LinkClick.aspx?fileticket=AiV3EqX0T8Q\%3d\&tabid=179

E.J. v. D.J., 14 A.3d 1136 (D.C. App. 2011)

Epstein, D. (1999). Effective Intervention in Domestic Violence cases: Rethinking the Roles of Prosecutors, Judges, and the Court System, 11 Yale J. L. \& Feminism 3

Frederick, L. (2008). Questions about Family Court Domestic Violence Screening and Assessment, 46 Fam. Ct. Rev. 523

Frye, V., Manganello, J., Campbell, J. C., Walton-Moss, B., \& Wilt, S. (2006). The Distribution of and Factors Associated With Intimate Terrorism and Situational Couple Violence Among a Population-Based Sample of Urban Women in the United States. J. of Interpersonal Violence 21:10 1286-1313

Hannah, M. \& Goldstein, B., Eds (2009). DOMESTIC VIOLENCE, ABUSE AND CHILD CUSTYODY: LEGAL STRATEGIES AND POLICY ISSUES (Civic Research Institute)

http://nursing.jhu.edu/faculty_research/faculty/faculty-directory/communitypublichealth/jacquelyn-campbell, last visited January 3, 2015

http://dangerassessment.org/AboutCreator.aspx, last visited January 3, 2015

http://www.leadershipcouncil.org/1/med/PR3.html, last visited December 22, 2012.

Holzworth-Munroe, A. \& Meehan, J. (2005). Typologies of Men who are Maritally Violent: Scientific and Clinical Implications, J. Interpersonal Violence 19:12, 1365-89

In re Morrison and Zacharia, WL 1163832 (Cal. Ct. App. 2009) 
Jaffe, P. G. Johnston, J.R., Crooks, C.V., \& Bala, N. (2008). Custody Disputes Involving Allegations of Domestic Violence: Toward a Differentiated Approach to Parenting Plans, 46 Fam. Ct. Rev. 500

Jaffe, P.G., Crooks, C.V. \& Poisson, S.E. (2003). Common Misperceptions in Addressing Domestic Violence in Child Custody Disputes. Juvenile and Family Court Journal, 54, 57-67

Jaffe, P.G., Lemon, N.K.D. \& Poisson, S. (2002). CHILD CUSTODY AND DOMESTIC VIOLENCE: A CALL FOR SAFETY AND ACCOUNTABILITY (Sage Publications)

JML v. CAL (2003), A-00660-02T3 Brief of Appellant, available at http://www.dvleap.org/LinkClick.aspx?fileticket=Oyo7BMkR5LI\%3d\&tabid=179

$J M L v C A L$, July 30, 2012 Opinion, Superior Court of New Jersey, Chancery Division (on file with author)

Johnson, M. (2008). A TyPology of DOMESTIC Violence: InTIMATE TERRORISM, Violent Resistance, AND Situational COUPLE Violence (Northeastern University Press)

Johnson, M., www.personal.psu.edu/mpg/MPG/Welcome.html

Johnson, M. (1995). Patriarchal Terrorism and Common Couple Violence: Two Forms of Violence Against Women, J. Marriage and the Family 57, 283-294

Johnson, M. P. \& Ferraro, K. (2000). Research on domestic violence in the 1990s: Making distinctions. Journal of Marriage and the Family, 62, 948-963

Johnson M. P. \& Leone, J. (2005). The Differential Effects of Intimate Terrorism and Situational Couple Violence, J. of Fam. Issues, 26:3, 322-349

Kelly, J.B. \& Johnson, M.P. (2008). Differentiation Among Types of Intimate Partner Violence: Research Update and Implications for Interventions, 46 Fam. Ct. Rev. 476

Leone, J.M., Johnson, M.P., Cohan, C.L. \& Lloyd, S.E. (2004). Conse quences of Male Partner Violence for Low-Income Minority Women, J. of Marriage and Family 66, 472-790

Malenko v. Handrahan (2009). 979 A.2d 1269 (Me.)

Mahoney, M. (1991). Legal Images of Domestic Violence: Redefining the Issue of Separation, 90 Mich. L. Rev. 1

Meier, J., Differentiating Domestic Violence Types: Profound Paradigm Shift, or Old Wine in New Bottles, in Goldstein B. \& Hannah, M., Eds., DOMESTIC VIOLENCE, ABUSE AND 
CHILD CUSTYODY: LEGAL STRATEGIES AND POLICY ISSUES VOL. 2 (forthcoming, Civic Research Institute: 2015)

Meier, J. (2009). A Historical Perspective on Parental Alienation Syndrome and Parental Alienation, Journal of Child Custody, 6:232-257

Meier, J. (2003). Domestic Violence, Child Custody and Child Protection: Understanding Judicial Resistance and Imagining the Solutions, 11 Am. U. J. Gender, Social Policy \& Law 657

Neustein, A. \& Lesher, M. (2005). FROM MADNESS TO MUTINY: WHY MOTHERS ARE RUNNING FROM THE FAMILY COURT AND WHAT TO DO ABOUT IT

Pence, E. Duluth Abuse Intervention Project, available at http://www.youtube.com/watch?v=r9dZOgr78eE, (last visited January 3, 2015)

Pence, E. \& Das DasGupta, S. (2006). Re-Examining 'Battering': Are All Acts of Violence Against Intimate Partners the Same? Praxis International, Inc., available at http://www.praxisinternational.org/files/praxis/files/ReexaminingBattering.pdf (last visited January 3, 2015)

Rosen, L. Dragiewicz, M. \& Gibbs, J.C. (2009). Fathers'Rights Groups: Demographic Correlates and Impact on Custody Policy, 15 Violence Against Women 513.

Salem, P., Kulak, D., \& Deutsch, R.M. (2007). Triaging Family Court Services: The Connecticut Judicial Branch's Family Civil Intake Screen, 27 Pace L. Rev. 741

Saunders, D.G., Faller, K.C. \& Tolman, R. M. (2011). Child Custody Evaluators' Beliefs About Domestic Abuse Allegations: Their Relationship to Evaluator Demographics, Background, Domestic Violence Knowledge and Custody-Visitation Recommendations, Final Technical Report Submitted to the National Institute of Justice, U.S. Department of Justice, Oct. 31, 2011, http://ssw.umich.edu/about/profiles/saunddan/Custody-Evaluators-Beliefs-About-DomesticAbuse-Allegations-Final-Tech-Report-to-NIJ-10-31-11.pdf

Sillito, C. (2012). Gendered Physical and Emotional Health Consequences of Situational Couple Violence for Heterosexual Married and Cohabiting Couples, Feminist Criminology, 7(4) 255-281

Stark, E. (2009). Rethinking Custody Evaluation in Cases Involving Domestic Violence, Journal of Child Custody 6:3, 287-321

Stark, E. (2006). Commentary on Johnson's Conflict and Control: Gender Symmetry and Asymmetry in Domestic Violence, 12:11 Violence Against Women 1019

Stephanie F. v. George C, 270 P. 3d 737 (Ala. 2012) 
Straus, M.A. (2009). Why the Overwhelming Evidence on Partner Phgysical Violence Has Not Been Perceived and is Often Denied, 18 J. Aggression, Maltreatment \& Trauma 552.

Straus, M. The Controversy Over Domestic Violence By Women: A Methodological, Theoretical, and Sociology of Science Analysis MenWeb Online Journal, ISSN: 1095-5240, http://www.batteredmen.com/straus21.htm, last visited 7/3/12

Swan, S. \& Snow, D. (2002). A Typology of Women's Use of Violence in Intimate Relationships, Violence Against Women, 8:3, 286-319

Tuerkheimer, D. (2004). Recognizing and Remedying the Harm of Battering: A Call to Criminalize Domestic Violence, 94 J. Crim. L. and Criminology 959

Ver Steegh, N. (2005). Differentiating Types of Domestic Violence: Implications for Child Custody, 65 La. L. Rev. 1379

Ver Steegh, N. \& Dalton, C. (2008). Report from the Wingspread Conference on Domestic Violence and Family Courts, 46 Fam. Ct. Rev. 454

Waits, K. (1998). Battered Women and Their Children: Lessons from One Woman's Story, 35 Hous. L. Rev. 29

Weitzman, S. (2000). NOT TO PEOPLE LIKE US: HidDEN ABUSE IN UPSCALE MARRIAGES (Basic Books)

Zibell, R.A. (2005). Common Couple Aggression: Frequency and Implications for Child Custody and Access Evaluations, 43:3, 454-465

Zorza, J. (2011). The New Domestic Violence Typologies: An Accurate Reconceptualization or Another Trivialization? 3 Family \& Intimate Violence Quarterly 225

\section{ENDNOTES}

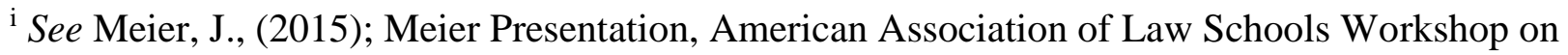
Family Law, Vancouver, Canada (June 2007); Meier Presentation, Jewish Women International's $4^{\text {th }}$ International Conference on Domestic Abuse, Crystal City, VA (April 2009); Meier Keynote, Seminar, University of Akron, Akron Bar Association and Cleveland Bar Association (September 2011), http://www.dvleap.org/Resources/TrainingMaterials.aspx (and on file with author)

iiJohnson's last two types are not discussed further herein. "Violent Resistance" describes women's violence in reaction to control-based (i.e., IT) violence: It is sometimes, but not always, self-defense, but may also be a violent reaction to a man's dominating violence.

"Mutual Violent Control" describes couples in which both parties vie for control with violence. 
Johnson is, however, uncertain whether this category exists in sufficient numbers to really examine (Johnson and Ferraro, 2000; M. Johnson, 2008, 23-24).

iiiThe court and evaluators ignored the child's own report that she no longer wanted to see him after he violently shook her in an altercation over a toothbrush, in her first visit to his new home.

iv Leone found 51\% SCV and 17\% IT, along with 32\% "control, no threat." If the last category is combined with IT, the rates of SCV and IT become virtually identical, and given that control is the defining characteristic of IT, it is not clear why the authors chose not to characterize the last $32 \%$ as IT. The label "no threat" is difficult to square with the fact that all of the couples studied had experienced violence. $I d$. at 486.

"Johnson also states that the "IT" and "SCV" populations he identified in the Pittsburgh data can be understood as those who rate high on all seven control behaviors, vs. those who rate low on all seven. (Johnson, 2008, 97). However, it seems illogical to call couples with "low" amounts of control on all seven control behaviors, "SCV." It seems at least as appropriate, if not more so, to consider them "low IT."

${ }^{v i}$ Johnson identifies the cut-point for the Pittsburgh data as 2.74, the cut-point for NVAWS as 3 or more control behaviors, and the cut-point in the Chicago Help-Seeking Study as 5. "Less controlling" couples are called SCV. In his study with Leone, they used a cut point of two or less (Johnson \& Leone, 2005).

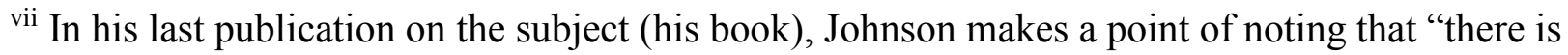
considerable variability in the violence involved in intimate terrorism" (Johnson, 2008, 30).

viii Stark writes "[i]t is unclear whether the violence in coercive control is typically severe as Johnson contends or consists of routine, low-level threats and assaults, as I believe." (Stark, 2006).

ix The brief describes Ms. L having had to get permission and to justify to her husband the spending of money, grocery shopping, children' clothes shopping, and even taking a bath.

${ }^{\mathrm{x}}$ In the $J M L$ case the history of ongoing minor violence and extreme control was ignored. The court then chose not to believe the one very serious incident of choking and sexual assault (JML v CAL, Opinion, 2002) 